\section{Microbiological and chemical evaluation of Helix spp. snails from local and non-EU markets, utilised as food in Sardinia}

\author{
Arianna Corda,, Laura Mara, ${ }^{2}$ \\ Sebastiano Virgilio,' Margherita Pisanu, \\ Giannina Chessa, ${ }^{2}$ Antonio Parisi, ${ }^{3}$ \\ Maria Paola Cogoni ${ }^{1}$ \\ 'Istituto Zooprofilattico Sperimentale \\ della Sardegna-Cagliari; ' ${ }^{2}$ stituto \\ Zooprofilattico Sperimentale della \\ Sardegna-Sassari; ${ }^{3}$ sstituto \\ Zooprofilattico Sperimentale della Puglia \\ e Basilicata-Putignano, Italy
}

\section{Abstract}

With this study, 28 pools of snails of the genus Helix, respectively Helix aspersa $(\mathrm{n}=24)$ and Helix vermiculata $(\mathrm{n}=4)$ were analysed. They were taken from snail farming and stores. The snails were from Sardinia, other regions of Italy, and from abroad. All the samples were examined as pool looking for these microbiological target: Salmonella spp., Listeria monocytogenes, Escherichia coli 0157, Clostridium perfringens, Norovirus and Hepatitis A Virus (HAV). In the same pools, the concentration of cadmium and lead by inductively coupled plasma mass spectrometry was also determined. The levels of these heavy metals were quite high, especially for cadmium. Two samples were positive for Salmonella spp., while no sample was positive for Escherichia coli 0157, HAV and Norovirus. Two samples were positive for Clostridium perfringens and 8 for Listeria monocytogenes. The microrganisms related to Listeria monocytogenes were identified using biochemical techniques, then serotyped and gene sequenced by multiple loci sequence typing technique. Furthermore, antimicrobial restistence was tested on the same samples.

\section{Introduction}

In Sardinia, the snail farming has its own important meaning related to the massive consume of the mollusk in the island and to the current limited presence of farms. Indeed, Sardinia has a high per-capita consumption, almost 8 times the average national one. In 2011 commercial data stated a consumption of 43,500 quintals. The $90 \%$ of this product (especially Helix aspersa and Helix aperta) is imported from North-Africa. Even though snails represent an economic and productive resource with interesting commercial and nutritive outlook, the need for specific microbiological and chemical requirements for these products is highlighted. From the data of European Food Safety Authority (EFSA) and of the European Centre for Disease Prevention and Control (ECDC) implementing the Directive 2003/99/CE about the monitoring of zoonoses and zoonotic agents, it is evident how infections caused by zoonotic bacteria mostly associated to human pathologies are caused by microorganisms conveyed by food, especially from microorganisms such as Salmonella spp., Campylobacter, Listeria monocytogenes, E.coli verocitotoxigenes (European Food Safety Authority, 2013). In snail farming it is good practice to take measures, both during breeding and during the phase of purging. In farming, the continuous control of the structure is needed to avoid problems related to the introduction of other animals. The rats are an obvious problem to be monitored especially in wintertime as these animals become intrusive and dangerous. Within the enclosure it is necessary to maintain a high level of hygiene and the removal of excreta, cleaning of the cages and the general disinfection of the structure are fundamental to control cross-contamination.

The present study was designed to obtain microbiological and chemical data with an impact on hygienic and toxicological risk of the snails eaten in Sardinia.

\section{Materials and Methods}

The snails were collected in $\mathrm{n}=7$ different farms located in the provinces of Cagliari and Sassari. Furthermore, other $n=10$ samples of different origin were collected in the provinces of Cagliari and Sassari. Two of them were from the wild, one from continental Italy, two from Greece, one from Algeria and four from Tunisia. Information regarding the farms subject of sampling are indicated in Table 1 . In none of snail farming the co-presence of other animal species was detected. For farms located in the drainage basin of the riu Montevecchio (Gonnosfanadiga, Guspini and Arbus), it is highlighted the risk of heavy metal pollution of surface water bodies and ground water subterranean due to the activities of mine. No other sources of pollution that could be linked to the other farms were aware.

In total, 28 pool of samples of non-operculate snails were examined, 24 belonged to Helix aspersa and 4 to Helix vermiculata. For the microbiological, virological and chemical analyses the following methods were applied: Listeria monocytogenes UNI EN ISO 11290-1:2005; Salmonella spp IS0 6579:2002; Escherichia coli 0157 IS0 16654:2001; Clostridium perfringens ISO 7937:2004. The determination of Norovirus GGI
Correspondence: Maria Paola Cogoni, Istituto Zooprofilattico Sperimentale della SardegnaSezione di Cagliari, Via dell'Acquedotto Romano, 09132 Elmas (CA), Italy.

Tel. +39.070.21914213 - Fax: +39.070 .2135121 .

E-mail: paola.cogoni@izs-sardegna.it

Key words: Food snails, Listeria monocytogenes, Toxic metals, Multilocus sequence typing, Microbiological evaluation.

Conflict of interest: the authors declare no potential conflict of interests.

Received for publication: 21 May 2013

Revision received: 17 September 2013

Accepted for publication: 2 October 2013

This work is licensed under a Creative Commons Attribution 3.0 License (by-nc 3.0).

(C) Copyright A. Corda et al., 2014

Licensee PAGEPress, Italy

Italian Journal of Food Safety 2014; 3:1732

doi:10.4081/ijfs.2014.1732

and GGII was performed according to Protocol of the National Reference Laboratory for Viral contamination in bivalve molluscs at the Istituto Superiore di Sanità, Rome - ISS, Determination of Norovirus and HAV in bivalve molluscs by RT conventional PCR and real-time PCR.

For the detection of Listeria monocytogenes, Salmonella spp., Escherichia coli 0157 and Clostridium perfringens, $25 \mathrm{~g}$ of sample (pooled specimens of snails) consisting of hepato-pancreas and pedal muscle were analysed. For the detection of Norovirus and HAV, the hepatopancreas was pulled out from 20 specimens, in order to have a pool of hepato-pancreas equal to $4 \mathrm{~g}$. For the determination of cadmium and lead, $1 \mathrm{~g}$ of pooled sample was analysed.

The analysis of Norovirus and HAV consisted of three phases: i) preparation of the sample and the concentration of viral particles; ii) extraction of the viral genome; iii) real-time polymerase chain reaction (RRT-PCR): a mix for the determination of each target (NoV GI, GII NoV, HAV) was prepared. The serotyping of the isolated Listeria monocytogenes has been done using commercial antisera distributed by Denka Seiken Co. (Tokyo, Japan) for the determination of the flagellar's agents $\mathrm{H}$ and somatic 0 (Parisi et al., 2010).

The antimicrobial susceptibility of the Listeria monocytogenes strains was determined in a semiquantitative way according to the disc-plate technique by Kirby-Bauer. The followings are the antibiotics used: ampicillin (10 g), ciprofloxacin (5 g), chloramphenicol (30 $\mathrm{g})$, erythromicyn (15 g), gentamicin (10 g), penicillin (10 g), rifampicin (30 g), streptomycin $(10 \mathrm{~g})$, sulfamethoxazol/trimethoprim $(1.25 / 23.75 \mathrm{~g})$, tetracycline (30 g) e van- 
comycin $(30 \mathrm{~g})$. The genes prfA, coding for the protein prfA which regulates the expression of the virulence genes and hlyA coding for the synthesis of Listeriolisina 0 (Aznar and Alarcon, 2002) were tested by multiplex-PCR technique. The multilocus sequence typing (MLST) scheme, used for the characterisation of the strains of Listeria monocytogenes, was based on the sequence of the following housekeeping genes: $\mathrm{ABC}$ transporter (acbZ), betaglucosidase (bglA), catalase (cat), succinyl diaminopimelate desuccinylase (dapE), Damino acido aminotransferase (dat), lattato deidrogenase (ldh), and istidina chinase (lhkA). The primers described by Salcedo et al . (2003) were used with the exception of the $l d h$ gene for which the primers suggested by an amended MLST scheme (Ragon et al., 2008) were used. The allocation of the sequence type (ST) has been done by the database Listeria MLST of the Pasteur Institute of Paris. The analytic determination of heavy metals was performed according to the EPA 3052 method for the sample's treatment and to the EPA $6020 \mathrm{~A}$ for the instrumental measurement.

\section{Results and Discussion}

The samples from farms n. 3 and 6 , resulted positive for Listeria monocytogenes (Table 2). The same results were also found in the sam-

Table 1. Typology of farms sampled in Sardinia.

\begin{tabular}{|c|c|c|c|c|c|c|c|}
\hline Farm & Species & Location & $\begin{array}{l}\text { Altitude } \\
\text { (m asl) }\end{array}$ & $\begin{array}{l}\text { Surface } \\
\left(\mathrm{m}^{2}\right)\end{array}$ & $\begin{array}{l}\text { Feed resource } \\
\text { for snail }\end{array}$ & $\begin{array}{l}\text { Farming } \\
\text { operation }\end{array}$ & $\begin{array}{l}\text { Breeding } \\
\text { management }\end{array}$ \\
\hline 1 & H. aspersa & $\begin{array}{c}\text { Gonnosfanadiga } \\
\text { (South/South-west) }\end{array}$ & 180 & 200 & $\begin{array}{l}\text { Beet, } \\
\text { sunflower, } \\
\text { thistle }\end{array}$ & $\begin{array}{l}\text { Collection, } \\
\text { purging, } \\
\text { drying }\end{array}$ & $\begin{array}{c}1 \text { breed from } \\
\text { continental Italy and } 1 \\
\text { breed from Sardinia }\end{array}$ \\
\hline 2 & $\begin{array}{l}\text { H. aspersa and } \\
\text { H. pomatia }\end{array}$ & $\begin{array}{c}\text { Guspini } \\
\text { (South/South-west) }\end{array}$ & 137 & 1300 & $\begin{array}{l}\text { Rape, } \\
\text { beet, } \\
\text { radish }\end{array}$ & $\begin{array}{l}\text { Collection, } \\
\text { purging, } \\
\text { drying }\end{array}$ & $\begin{array}{c}\text { Breeds from } \\
\text { Italian and Sardinian } \\
\text { company }\end{array}$ \\
\hline 3 & $\begin{array}{l}\text { H. aspersa and } \\
\text { H. aperta }\end{array}$ & $\begin{array}{c}\text { Serrenti } \\
\text { (Center/South) }\end{array}$ & 114 & 5000 & $\begin{array}{l}\text { Rape, beet, } \\
\text { radish, grasses }\end{array}$ & $\begin{array}{l}\text { Collection, purging } \\
\text { drying, packaging }\end{array}$ & $\begin{array}{l}\text { Breeds from Italian } \\
\text { company }\end{array}$ \\
\hline 4 & H. aspersa & $\begin{array}{c}\text { Gonnosfanadiga } \\
\text { (South/South-west) }\end{array}$ & 180 & 400 & $\begin{array}{l}\text { Cabbage, kale, } \\
\text { chard, chicory }\end{array}$ & $\begin{array}{c}\text { Collection, purging, } \\
\text { drying, packaging }\end{array}$ & - \\
\hline 5 & H. aspersa & $\begin{array}{c}\text { Osilo } \\
\text { (Northwest) }\end{array}$ & 672 & 2500 & $\begin{array}{l}\text { Beet, flours of } \\
\text { corn and barley }\end{array}$ & - & Breeds from Sicily \\
\hline 6 & H. aspersa & $\begin{array}{c}\text { Sassari } \\
\text { (Apparreddu) }\end{array}$ & 225 & 5000 & $\begin{array}{l}\text { Beets, corn, bran, } \\
\text { barley, vitamins, } \\
\text { carbonates and } \\
\text { sulphates of calcium }\end{array}$ & - & Breeds from Sicily \\
\hline 7 & H. aspersa & $\begin{array}{c}\text { Sassari } \\
\text { (S. Maria La Palma) }\end{array}$ & 225 & 1500 & $\begin{array}{l}\text { Beet, feed and } \\
\text { corn flours }\end{array}$ & - & Breeds from Sicily \\
\hline
\end{tabular}

Table 2. Results of sampling of snails made in snail farmings.

\begin{tabular}{|c|c|c|c|c|c|c|c|c|}
\hline $\begin{array}{l}\text { N. snail } \\
\text { farming }\end{array}$ & Species & $\begin{array}{c}\text { Salmonella } \\
\text { spp. }\end{array}$ & $\begin{array}{c}\text { Listeria }^{\circ} \\
\text { spp. }\end{array}$ & $\begin{array}{l}\text { Cl. perfringens } \\
\text { (ufc/gr) }\end{array}$ & Norovirus" & $\mathrm{HAV}^{\#}$ & $\begin{array}{l}\text { Cadmium }^{\S} \\
\text { (mg/kg) }\end{array}$ & $\begin{array}{c}\text { Lead }^{\S} \\
(\mathrm{mg} / \mathrm{kg})\end{array}$ \\
\hline 1 & Helix aspersa & $\begin{array}{l}\text { nd } \\
\text { nd }\end{array}$ & $\begin{array}{l}\text { nd } \\
\text { nd }\end{array}$ & $\begin{array}{l}<10 \\
<10\end{array}$ & $\begin{array}{l}\text { nd } \\
\text { nd }\end{array}$ & $\begin{array}{l}\text { nd } \\
\text { nd }\end{array}$ & $\begin{array}{c}1.61 \\
\mathrm{nr}\end{array}$ & $\begin{array}{c}0.30 \\
\mathrm{nr}\end{array}$ \\
\hline 2 & Helix aspersa & $\begin{array}{l}\text { nd } \\
\text { nd }\end{array}$ & $\begin{array}{l}\text { nd } \\
\text { nd }\end{array}$ & $\begin{array}{l}<10 \\
<10\end{array}$ & $\begin{array}{l}\text { nd } \\
\text { nd }\end{array}$ & $\begin{array}{l}\text { nd } \\
\text { nd }\end{array}$ & $\begin{array}{l}1.73 \\
2.54\end{array}$ & $\begin{array}{l}0.12 \\
0.29\end{array}$ \\
\hline 3 & Helix aspersa & $\begin{array}{l}\text { nd } \\
\text { nd } \\
\text { nd } \\
\text { nd }\end{array}$ & $\begin{array}{l}\text { nd } \\
\text { d } \\
\text { d } \\
\text { d }\end{array}$ & $\begin{array}{c}80 \\
30 \\
<10 \\
<10\end{array}$ & $\begin{array}{l}\text { nd } \\
\text { nd } \\
\text { nd } \\
\text { nd }\end{array}$ & $\begin{array}{l}\text { nd } \\
\text { nd } \\
\text { nd } \\
\text { nd }\end{array}$ & $\begin{array}{l}0.55 \\
0.44 \\
0.69 \\
0.80\end{array}$ & $\begin{array}{l}0.25 \\
0.24 \\
0.37 \\
0.55\end{array}$ \\
\hline 4 & Helix aspersa & $\begin{array}{l}\text { nd } \\
\text { nd } \\
\text { nd } \\
\text { nd } \\
\text { nd }\end{array}$ & $\begin{array}{l}\text { nd } \\
\text { nd } \\
\text { nd } \\
\text { nd } \\
\text { nd }\end{array}$ & $\begin{array}{l}<10 \\
<10 \\
<10 \\
<10 \\
<10\end{array}$ & $\begin{array}{l}\text { nd } \\
\text { nd } \\
\text { nd } \\
\text { nd } \\
\text { nd }\end{array}$ & $\begin{array}{l}\text { nd } \\
\text { nd } \\
\text { nd } \\
\text { nd } \\
\text { nd }\end{array}$ & $\begin{array}{l}3.75 \\
3.92 \\
4.01 \\
3.40 \\
3.83\end{array}$ & $\begin{array}{l}0.70 \\
0.25 \\
0.52 \\
1.12 \\
0.71\end{array}$ \\
\hline 5 & Helix aspersa & nd & nd & $<10$ & nd & nd & 0.08 & 0.05 \\
\hline 6 & Helix aspersa & $\begin{array}{l}\text { nd } \\
\text { nd } \\
\text { nd }\end{array}$ & $\begin{array}{l}\mathrm{d} \\
\mathrm{d} \\
\mathrm{d}\end{array}$ & $\begin{array}{l}<10 \\
<10 \\
<10\end{array}$ & $\begin{array}{l}\text { nd } \\
\text { nd } \\
\text { nd }\end{array}$ & $\begin{array}{l}\text { nd } \\
\text { nd } \\
\text { nd }\end{array}$ & $\begin{array}{c}1.06 \\
\mathrm{nr} \\
\mathrm{nr}\end{array}$ & $\begin{array}{c}0.06 \\
\mathrm{nr} \\
\mathrm{nr}\end{array}$ \\
\hline 7 & Helix aspersa & nd & nd & $<10$ & nd & nd & $\mathrm{nr}$ & $\mathrm{nr}$ \\
\hline
\end{tabular}

HAV, hepatitis a virus; nd, not detected; d, detected; nr, not received. ${ }^{\circ} 25 \mathrm{~g}$ of sample (pooled specimens of snails) consisting of hepatopancreas more muscle pedal were analysed; ${ }^{\star 2} 0$ specimens from which hepatopancreas was derived were used to have a pool of hepatopancreas equal to $4 \mathrm{~g}$; sthese metals were used in a pool of snails so that $1 \mathrm{~g}$ of sample was analysed. 
ples of snails from Greece and Tunisia (Table 3). In two samples from farm n. 3, apart from the presence of Listeria monocytogenes, also Clostridium perfringens was found in amount of 80 and $30 \mathrm{ufc} / \mathrm{g}$ respectively. In two samples, one from Tunisia e one from the wild collection in Sardinia, a strain of Salmonella Zanzibar and one of Salmonella Arapahoe were found. Similar results have been reported by other authors (Marongiu et al., 1993; Tedde et al., 2009). No one of the tested sample was found with positive analytical result for Escherichia coli 0157, Norovirus and HAV.

Most of the strains of Listeria monocytogenes were responsive to almost all of the antimicrobial tested. All of the strains $(n=8)$ were sensible to the tetracycline, gentamicin, erythromycin, vancomycin and to the combination sulfamethoxazol-trimethoprim. Various reactions were highlighted for the ciprofloxacin. Furthermore, six strains out of eight showed an intermediate resistance. Only one strain manifested an intermediate resistance to streptomycin.

In each of the isolated bacterial strains of Listeria monocytogenes the hlyA gene was found, while the prfA gene was found in five of them. All of the isolated strains of Listeria monocytogenes that were analysed belong to two serotypes: $1 / 2 \mathrm{a}$ and $4 \mathrm{~b} / 4 \mathrm{e}$. The serotype $1 / 2 \mathrm{a}$ belongs to the II genetic line while the serotype $4 \mathrm{~b} / 4 \mathrm{e}$ belongs to the I genetic line.

The MLST allowed to find 6 STs: ST217, ST37, ST1, ST2, ST204, ST7. Two strains had ST7 and two ST204. The isolated belonged to two main genetic lines (I, II). The I genetic line did not have the coding gene for the prfA protein and included three strains with serotype $4 \mathrm{~b} / 4 \mathrm{e}$, two from the farm n. 3 and one from the farm n.6. The II genetic line included strains that involve the virulence genes prfA and hlyA with serotype $1 / 2 a$, one from the farm n. 3, two from the farm n.6, one from Tunisia and another from Greece (Table 4).

Regarding heavy metals, the maximum level of contamination for both the examined metals were noticed in farm n.4 located in the municipality of Gonnosfanadiga. This finding has been confirmed by the analysis of several samples of the same breeding in different periods of the year, hence in different growth and feed conditions. For the other sampling zones, lead and cadmium showed medium-high values in farms n. 2 and 3 and in one sample collected in the market. Minimum levels were registered in the sample of Helix aspersa took in farm n. 5 .

\section{Conclusions}

This study allowed to acquire information on the microbiological and chemical contamination in locally-sourced and and importedfrom-outside snails for alimentary purpose in Sardinia. Related to the contamination of Salmonella Zanzibar, Salmonella Arapahoe and Listeria monocytogenes it must be underlined that, even though they represent a risk, the type of treatment that snails usually are submitted to must be considered because correct cooking reduces the risk. The traditional cooking presupposes a long thermal treatment before consumption and considered that the whole body of the snail is consumed, this opens up the field to possible cross contamination with foods which do not require any thermal treatment before the consumption or also

Table 3. Results of sampling of snails from local and non-EU countries made in shops.

\begin{tabular}{|c|c|c|c|c|c|c|c|c|}
\hline $\begin{array}{l}\text { Country } \\
\text { of origin }\end{array}$ & Species & $\begin{array}{c}\text { Salmonella } \\
\text { spp. }^{\circ}\end{array}$ & $\begin{array}{c}\text { Listeria }^{\circ} \\
\text { m. }^{\circ}\end{array}$ & $\begin{array}{l}\text { Cl. perfiningens }{ }^{\circ} \\
\text { (ufc/g) }\end{array}$ & Norovirus" & $\mathrm{HAV}^{*}$ & $\begin{array}{c}\text { Cadmium }^{\S} \\
(\mathrm{mg} / \mathrm{kg})\end{array}$ & $\begin{array}{l}\text { Lead\$ }^{\S} \\
(\mathrm{mg} / \mathrm{kg})\end{array}$ \\
\hline Algeria & Helix aspersa & nd & nd & $<10$ & nd & nd & 0.44 & 0.22 \\
\hline Tunisia & Helix aspersa & nd & nd & $<10$ & nd & nd & $\mathrm{nr}$ & $\mathrm{nr}$ \\
\hline Tunisia & Helix aspersa & nd & nd & $<10$ & nd & nd & $\mathrm{nr}$ & $\mathrm{nr}$ \\
\hline Tunisia & Helix aspersa & nd & nd & $<10$ & nd & nd & 1.88 & 0.78 \\
\hline Tunisia & Helix vermiculata & nd & nd & $<10$ & nd & nd & 1.26 & 0.08 \\
\hline Greece & Helix vermiculata & nd & $\mathrm{d}$ & $<10$ & nd & nd & $\mathrm{nr}$ & $\mathrm{nr}$ \\
\hline Greece & Helix aspersa & nd & nd & $<10$ & nd & nd & $\mathrm{nr}$ & $\mathrm{nr}$ \\
\hline Italy & Helix vermiculata & nd & nd & $<10$ & nd & nd & 1.76 & 0.27 \\
\hline Sardinia & Helix vermiculata & $d$ & nd & $<10$ & nd & nd & 0.69 & 0.05 \\
\hline Sardinia & Helix aspersa & nd & nd & $<10$ & nd & nd & $\mathrm{nr}$ & $\mathrm{nr}$ \\
\hline
\end{tabular}

HAV, hepatitis a virus; nd, not detected; d, detected; nr, not received.

${ }^{\circ} 25 \mathrm{~g}$ of sample (pooled specimens of snails) consisting of hepatopancreas more muscle pedal were analysed; ${ }^{\ddagger} 20$ specimens from which hepato-pancreas was derived were used to have a pool of hepatopancreas equal to $4 \mathrm{~g}$; sthese metals were used in a pool of snails so that $1 \mathrm{~g}$ of sample was analysed.

Table 4. Results of serotyping, analysis of virulence factors by multilocus sequence typing research on strains of Listeria monocytogenes isolates.

\begin{tabular}{|c|c|c|c|c|c|c|c|}
\hline Origin & Species & Listeria m. & ST & Serotype & Genetic line & \multicolumn{2}{|c|}{ Genes presence } \\
\hline Snail farming n. 3 & Helix aspersa & $\begin{array}{l}d \\
d \\
d\end{array}$ & $\begin{array}{c}\text { ST217 } \\
\text { ST37 } \\
\text { ST1 }\end{array}$ & $\begin{array}{c}4 \mathrm{~b} / 4 \mathrm{e} \\
1 / 2 \mathrm{a} \\
4 \mathrm{~b} / 4 \mathrm{e}\end{array}$ & $\begin{array}{l}\text { I } \\
\text { II } \\
\text { I }\end{array}$ & $\begin{array}{c}\text { nd } \\
\text { d } \\
\text { nd }\end{array}$ & $\begin{array}{l}d \\
d \\
d\end{array}$ \\
\hline Snail farming n. 6 & Helix aspersa & $\begin{array}{l}d \\
d \\
d\end{array}$ & $\begin{array}{c}\text { ST2 } \\
\text { ST204 } \\
\text { ST7 }\end{array}$ & $\begin{array}{c}4 \mathrm{~b} / 4 \mathrm{e} \\
1 / 2 \mathrm{a} \\
1 / 2 \mathrm{a}\end{array}$ & $\begin{array}{l}\text { I } \\
\text { II } \\
\text { II }\end{array}$ & $\begin{array}{l}\text { nd } \\
\text { d } \\
\text { d }\end{array}$ & $\begin{array}{l}\text { d } \\
\text { d } \\
\text { d }\end{array}$ \\
\hline Tunisia & Helix aspersa & d & ST204 & $1 / 2 \mathrm{a}$ & II & d & d \\
\hline Greece & Helix vermiculata & d & ST7 & $1 / 2 \mathrm{a}$ & II & d & d \\
\hline
\end{tabular}

ST, sequence type; nd, not detected; d, detected. 
the possibility to contaminate humans during the manipulating phase and the harvest. Clostridium perfringens, due to the thermostable spores which can germinate and proliferate (Sartory et al., 1998), differs from the strictly vegetative bacteria. Indeed, some strains of Clostridium perfringens are the cause of the third most common foodborne disease in the United States. Our data suggests that snails are a favourable substrate for the growth of the Listeria genus, including the Listeria monocytogenes species and some serotypes of Salmonella.

The evidence that most of the strains of Listeria monocytogenes were sensible to almost all the tested antimicrobial, suggests that the total resistance to the antibiotics of Listeria monocytogenes isolated in commercialised snails in Sardinia is low, and this data is apparently caused by the low employment of antimicrobial in snails farms, in contrast to what frequently happens in human medicine and veterinary. These substances are used for animals therapy, prophylaxis or growth promotion. Also, the analysis performed with MLST that underlined the result of clones often involved in clinic cases, seemed to suggest that snails are a potential reservoir for the cross-contamination of Listeria monocytogenes. The data obtained suggest the adoption of appropriate control measures, yet not sufficient.

The Reg. EC n. 853/2004 (European Commission, 2004) states specific rules about the hygiene of the food of animal origin and reserves to snails (and frogs) only a few lines. Nowadays the need for a common rule to discipline the production and commercialisation of the snails and all others products of the snail farming together with the wellness of the animals is always more stringent. The absence or the limited presence of information for this specific sector does not guarantee the consumer and discourages the business for farming and marketing. Veterinary controls are the last part of the productive chain. Clear rules are needed for the labelling, traceability and the origin of the snails that reach the market. In Italy this issue is deeply felt because together with Spain and Greece, it is the country with the largest consuming rates.

For the chemical contamination the results are different zone by zone. Cadmium represents the highest risk, in the $63 \%$ of the analysed samples the amount of this metal is over 1 $\mathrm{mg} / \mathrm{kg}$, using this value as a reference for comparison to bivalve mollusks (Reg. EC n. 1881/2006; European Commission, 2006). The small number of samples does not allow us to make comparisons with the data in the literature (Ghidini et al., 2003; Scaffardi et al., 2007; Storelli and Marcotrigiano, 2001), this in relation also to the different species of snails analysed. However, it must be highlighted that the concentration of cadmium of our samples was higher than that reported by other authors.

Levels of heavy metals contamination in farmed products resulted to be particularly high, to confirm the fact that the quality of the environment of the production's zone has a significant impact on snail contamination. This makes it necessary to have a more strict regulation regime in order to authorise the snail farming.

The contamination level of cadmium is high and not negligible. Just a portion of snails is sufficient to cover the $40.3 \%$ of the tolerable weekly intake. However, it must be underlined that the consumption of snails is occasional and coincides with local food habits and has no place in the daily diet.

\section{References}

Aznar R, Alarcon B, 2002. On the specificity of PCR detection of Listeria monocytogenes in food: a comparison of published primers. Syst. Appl. Microbiol 25:109-19.

European Commission, 2004. Regulation of the European Parliament and the Council of 29 April 2004 laying down specific hygiene rules for on the hygiene of foodstuffs, 853/2004/EC. In: Official Journal, L L 139, 30/04/2004, p. 55-205.

European Commission, 2006. Regulation of 19 December 2006 setting maximum levels for certain contaminants in foodstuffs, 1881/2006/EC. In: Official Journal, L 2006R1881.

European Food Safety Authority, 2013. The
European Union summary report on trends and sources of zoonoses, zoonotic agents and food-borne outbreaks in 2011. EFSA J 11:3129.

Ghidini S, Novelli E, Battaglia A, Campanini G, Balzan S, Bracchi PG, 2003. Valutazioni elementari su molluschi terrestri appartenenti al genere Helix. Ann Fac Medic Vet Parma 23:163-8.

Marongiu E, Virgilio S, Sias S, Santoru F, 1993. [Aspetti igienico-sanitari di chiocciole utilizzate a scopo alimentare in Sardegna]. [Proc. in Italian]. Proc. 47th Nat. Congr. It. Soc. Vet. Sci., pp 679-82.

Parisi A, Lattorre L, Normanno G, Miccolupo A, Fraccalvieri R, Vanessa L, Santagada G, 2010. Amplified fragment polymorphism and multi-locus sequence typing for highresolution genotyping of Listeria monocytogenes from foods and the environment. Food Microbiol. 27:101-8.

Ragon M, Wirth T, Hollandt F, Lavenir R, Lecuit M, Le MA, Brisse S, 2008. A new perspective on Listeria monocytogenes evolution. PloS Pathog 4:e1000146.

Salcedo C, Arreazza L, Alcala B, de la FL, Vazquez JA, 2003. Development of a multi locus sequence typing method for analysis of Listeria monocytogenes clones. J Clin Microbiol 41:757-62.

Sartory DP, Field M, Curbishley SM, Pritchard AM, 1998. Evaluation of two media for the membrane filtration enumeratio of Clostridium perfringens from water. Lett Appl Microbiol 27:323-7.

Scaffardi E, Ru G, Giordana G, Tarasco R, Palmegiano P, Crescio ML, Abete MC, 2007. [Accumulo di metalli pesanti in chiocciole della specie Helix pomatia L. (Pulmonata, Helicidae) destinate al consumo umano]. [Book in Italian]. Il Chirone 1:8-11.

Storelli MM, Marcotrigiano G0, 2001. Heavy metals $(\mathrm{Hg}-\mathrm{Pb}-\mathrm{Cd}-$ and $\mathrm{Cr})$ in edible snails. Ital J Food Sci 13:399-404.

Tedde T, Virgilio S, Chessa G, Fiori G, Terrosu G, Rosa MN, Pinna C, Piras G, 2009. [Rilievi microbiologici in gasteropodi terrestri commercializzati nella regione Sardegna]. Rivista AIVI 5:23-7. 